\title{
Bacterial protein microarrays for identification of new potential diagnostic markers for Neisseria meningitidis infections
}

\author{
Sigrid Steller ${ }^{1}$, Philipp Angenendt ${ }^{1}$, Dolores J. Cahill ${ }^{2,3,4}$, Sigrid Heuberger ${ }^{5}$, \\ Hans Lehrach ${ }^{1}$ and Jürgen Kreutzberger ${ }^{1}$ \\ ${ }^{1}$ Max-Planck-Institute for Molecular Genetics, Berlin, Germany \\ ${ }^{2}$ Ruhr-University Bochum, Medical Proteome Center, Bochum, Germany \\ ${ }^{3}$ PROTAGEN AG, Dortmund, Germany \\ ${ }^{4}$ The Centre for Human Proteomics, Royal College of Surgeons in Ireland, Dublin, Ireland \\ ${ }^{5}$ Nationale Referenzzentrale für Meningokokken, AGES BSU-Graz, Graz, Austria
}

\begin{abstract}
Neisseria meningitidis is the most common cause of meningitis and causes epidemic outbreaks. One trait of $N$. meningitidis, which is associated with most of the currently recognized virulence determinants, is the presence of phase-variable genes that are suspected to enhance its ability to cause an invasive disease. To detect the immune responses to phase-variable expressed proteins, we applied protein microarray technology for the screening of meningitis patient sera. We amplified all 102 known phase-variable genes from $N$. meningitidis serogroup B strain MC58 by polymerase chain reaction and subcloned them for expression in Escherichia coli. With this approach, we were able to express and purify 67 recombinant proteins representing $66 \%$ of the annotated genes. These were spotted robotically onto coated glass slides to generate protein microarrays, which were screened using 20 sera of patients suffering from meningitis, as well as healthy controls. From these screening experiments, 47 proteins emerged as immunogenic, exhibiting a variable degree of seroreactivity with some of the patient sera. Nine proteins elicited an immune response in more than three patients, with one of them, the phase-variable opacity protein OpaV (NMB0442), showing responses in 11 patient sera. This is the first time that protein microarray technology has been applied for the investigation of genetic phase variation in pathogens. The identification of disease-specific proteins is a significant target in biomedical research, as such proteins may have medical, diagnostic, and commercial potential as disease markers.
\end{abstract}

Received: April 6, 2004

Revised: October 4, 2004 Accepted: October 28, 2004

\section{Keywords:}

Opacity proteins / Pathogen / Phase variation / Protein chip / Vaccine

\section{Introduction}

Neisseria meningitidis is the major causative agent of bacterial meningitis. Over 500000 meningococcal cases occur each year, a number that is frequently accentuated by large

Correspondence: Dr. Jürgen Kreutzberger, Max-Planck-Institute for Molecular Genetics, Ihnestrasse 73, D-14195 Berlin, Germany E-mail: kreutzbg@molgen.mpg.de

Fax: +49-30-8413-1128

Abbreviations: dNTP, deoxynucleotide triphosphate; IPTG, isopropyl- $\beta$-D-thiogalactoside; NMB, Neisseria meningitidis serogroup B epidemic outbreaks especially in the African meningitis belt [1]. These numbers have put bacterial meningitis into the list of the top ten infectious causes of death worldwide. N. meningitidis is an exclusively human commensal and pathogen. To survive as a human upper respiratory commensal and occasionally as a bloodstream invader, the meningococcus has evolved novel and sophisticated genetic mechanisms, most notably the phase variation. Many genes are subject to phase variation, including pili [2], capsule [3], outer membrane proteins $[4,5]$, hemoglobin receptors [6], and lipooligosaccharides [7]. Phase variation has been proposed to enhance the capacity of the organism to cause invasive disease. Virji et al. $[8,9]$ showed in in vitro studies 
that adhesion to or particularly invasion of epithelial cells were enhanced by the presence of certain opacity (Opa) proteins.

Phase variable addition of sialic acid to capsular polysaccharides or lacto- $N$-neotetraose structures of lipopolysaccharides can occur with a frequency of $10^{-3}-10^{-4}$ per generation [10]. Phase variation of surface sialic acids is involved in host invasion and may implicate phenotypic transitions, so the sialization status is correlated to the three phenotypes: transmission phenotype (sialylated), colonizing phenotype (asialylated), and disseminating phenotype (sialylated). In such a model of meningococcal pathogenesis, Opa proteins may contribute significantly to host invasion [3].

For N. meningitidis strain MC58, 102 putative phase-variable genes were described, the largest repertoire of phasevariable genes in any species to date [11]. The phase variation process generally requires the presence of repeated nucleotide tracts within the coding or the promoter region [12, 13]. Additionally, a new mechanism of phase variation was identified for nadA, in which a repeat tract was located upstream of the putative -35 element of the nadA promoter [14]. The instability of these repeats during replication can shift reading frames or alter the strength of promoters, thus affecting gene expression [15].

Identification of $N$. meningitidis is normally performed after culturing the bacteria isolated from cerebrospinal fluid (CSF), following biochemical investigation or antigen detection by latex agglutination. Sometimes the bacteria can be identified in microscopic examinations of the spinal fluid. The WHO postulates more specialized laboratory tests for the identification of serogroups as well as for testing the sensibility to antibiotics (WHO Fact sheet $N^{\circ} 141$; http:// www.who.int/mediacentre/factsheets/fs141/en/). PCR diagnosis has become of special interest, but has not been fully established in routine laboratory use [16, 17]. Moreover, PCR is not suited to describe the protein expression of phasevariable expressed genes and to monitor the antibody content against these proteins in serum samples, which is the aim of our study.

Miniaturized and parallel assay systems, especially microarray-based analysis, are crucial to large-scale and highthroughput biological analysis, as they are rapid and economic to interpret gene function [18-20]. In the microarray format, capture molecules are immobilized at highdensity on a solid support, and probed for various biochemical activities. The microarray format has the advantage that thousands of proteins can be screened simultaneously in an automated fashion with very small consumption of serum. In the past years several protein microarray methodologies have been developed for the high-throughput investigation of proteins. Some approaches applied cDNA expression libraries [21-23], others employed antibodies or proteins for the screening of interactions [24-31]. For example, protein microarrays have been used for the analysis of autoantibody responses to distinguish autoimmune diseases [32]. In this study we used protein microarrays to identify $N$. meningitidis proteins for potential diagnostic purposes.

\section{Materials and methods}

\subsection{Choice of genes}

All 102 phase-variable genes of N. meningitidis strain MC58 $[12,13]$ were selected for PCR amplification.

\subsection{PCR}

All primers had ten nucleotide adaptor regions containing a restriction enzyme recognition site (XhoI in the 5'end, $B s p 120 \mathrm{~L}$ in the 3'end) followed by a 21 nucleotides gene-specific part. Primer sequences for the adaptor sites were as follows: XhoI: GCC TCG AGG, Bsp120L: G GAT GGG CCC. The 5' primers were designed to be in-frame with the RGS$\mathrm{His}_{6}$ encoding reading frame. For genes annotated with an authentic frameshift, resulting in the disruption of one single ORF, we used two different strategies: for genes with an ORF interruption near the 5' end, we designed primers binding 3' of this interruption, resulting in one shortened ORF. For genes with an interruption in the middle, we designed two separate primer pairs flanking this disruption, resulting in the generation of two recombinant proteins for one disrupted gene. PCR amplification was performed with Platinum Pfx DNA Polymerase (Invitrogen, Groningen, The Netherlands). PCR was performed in $50 \mu \mathrm{L}$ batches with a reaction mixture containing $235 \mathrm{ng}$ plasmid DNA, $10 \mathrm{pmol}$ primer, $10 \mathrm{~mm}$ dNTPs, and reaction buffer. PCR was performed at $94^{\circ} \mathrm{C}$ for $2 \mathrm{~min}$, followed by 25 cycles of $94^{\circ} \mathrm{C}$ for $30 \mathrm{~s}, 55^{\circ} \mathrm{C}$ for $1 \mathrm{~min}$, and $68^{\circ} \mathrm{C}$ for $90 \mathrm{~s}$ and finished with a final elongation at $68^{\circ} \mathrm{C}$ for $7 \mathrm{~min}$. PCR products were purified with a QIAquick PCR purification kit (Qiagen, Hilden, Germany).

\subsection{Cloning}

Purified PCR products were digested with XhoI and Bsp120L (using $50 \mathrm{U}$ each) and ligated to the expression vector pQE32-NST-BTattB (a derivative of pQE30NST; GI:3328183) previously digested with NotI and SalI. The ligation mixture was transformed into chemically-competent Escherichia coli SCS1 cells harboring a pSE111 helper plasmid, carrying lacI ${ }^{\mathrm{q}}$ and kanamycin resistance [21]. Cells were then grown for $16 \mathrm{~h}$ at $37^{\circ} \mathrm{C}$ on Luria broth (LB) agar plates containing ampicillin $(100 \mu \mathrm{g} / \mathrm{mL})$, kanamycin $(25 \mu \mathrm{g} / \mathrm{mL})$, and glucose $(5 \% \mathrm{w} / \mathrm{v})$. Clones were picked and grown for $16 \mathrm{~h}$ at $37^{\circ} \mathrm{C}$ on LB plates as described above. Cells were harvested and plasmid DNA was isolated with a Qiagen BioRobot 8000 and the MagAttract 96 Miniprep system. Isolated DNA was digested with EcoRI, analyzed by agarose gel electrophoresis, and positive clones were verified by sequencing. 


\subsection{Protein expression and purification}

Clones were grown for $16 \mathrm{~h}$ at $37^{\circ} \mathrm{C}$ in deep-well microtiter plates containing $1 \mathrm{~mL}$ LB medium with ampicillin $(100 \mu \mathrm{g} /$ $\mathrm{mL})$, kanamycin $(25 \mu \mathrm{g} / \mathrm{mL})$, and glucose $(5 \% \mathrm{w} / \mathrm{v})$. After $16 \mathrm{~h}, 200 \mu \mathrm{L}$ culture medium was transferred to $2 \mathrm{~mL} \mathrm{LB}$ containing ampicillin $(100 \mu \mathrm{g} / \mathrm{mL})$ and kanamycin $(25 \mu \mathrm{g} /$ $\mathrm{mL})$. Protein expression was induced after $2.5 \mathrm{~h}$ incubation at $37^{\circ} \mathrm{C}$ by addition of isopropyl- $\beta$-D-thiogalactoside (IPTG) (1 $\mathrm{mm}$ final concentration). Four hours after induction, the cells were harvested by centrifugation at $1500 \times \mathrm{g}$ for $15 \mathrm{~min}$ at $4^{\circ} \mathrm{C}$. Protein purification was carried out with a Qiagen BioRobot 8000 and the Ni-NTA Superflow 96 BioRobot Kit using a protocol for purification under denaturing conditions. Proteins were analyzed on a $12.5 \%$ polyacrylamide gel containing SDS and their molecular weights were determined. The protein concentration was determined using the Bradford assay [33].

\subsection{Generation of protein microarrays}

We used FAST Slides, which have a $14 \mu \mathrm{m}$ thick NC-based coating in a size of $20 \mathrm{~mm} \times 50 \mathrm{~mm}$ (Schleicher \& Schuell, Dassel, Germany). Proteins or antibodies were spotted in a $4 \times 4$ pattern using a QArray system (Genetix, Hampshire, UK) equipped with humidity control (60\%) and 16 blunt ended stainless steel print tips with a tip diameter of $150 \mu \mathrm{m}$. Purified proteins were spotted in duplicate with a spot center to center distance of $1250 \mu \mathrm{m}$ in an uniform pattern in two identical fields. In addition to $N$. meningitidis proteins, we also spotted dilution series of unlabeled antibodies against human IgG and IgM to normalize the microarrays.

\subsection{Sera}

In this study sera from 20 male and female convalescent patients aged from 8 months to 33 years were obtained from AGES BSU-Graz, Austria. Sera from control persons (sex and age matched, without meningitis) were obtained from the DRK Kliniken (Berlin, Germany). Detailed information (age, sex, and diagnosis) is presented in Table 1.

\subsection{Serum screening}

The protein microarrays were blocked for $3 \mathrm{~h}$ with blocking solution $(0.05 \% \mathrm{v} / \mathrm{v}$ Tween $20,3 \% \mathrm{v} / \mathrm{v}$ fetal calf serum (Invitrogen, Karlsruhe, Germany) in $1 \times$ PBS). The proteins were later incubated with sera diluted in blocking solution (1:100) at $4{ }^{\circ} \mathrm{C}$ overnight, using a volume of $200 \mu \mathrm{L}$ for each microarray covered by a cover slip. The microarrays were then washed five times for $10 \mathrm{~min}$ in $1 \times$ PBS and incubated with a secondary antibody (rabbit anti-human IgG-Cy5; Dianova, Hamburg, Germany) diluted 1:800 in blocking solution. After $2 \mathrm{~h}$ of incubation, the microarrays were washed again five times for $10 \mathrm{~min}$ in $1 \times$ PBS and finally in distilled water for $5 \mathrm{~min}$. The microarrays were air-dried and scanned.

\subsection{Scanning}

A ScanArray 4000 (Perkin Elmer Life Sciences, Cologne, Germany) was used to scan the slides with the following settings: laser power 100\% for Cy5 $649 \mathrm{~nm}$ excitation/emission $670 \mathrm{~nm}$, photomultiplier tube (pmt) was 30-40\%. The resolution of scanning was $10 \mu \mathrm{m}$.

\subsection{Computer analysis}

For image analysis, we used GenePix Pro v 4.0 with local background subtraction mode (Axon Instruments, Union City, CA, USA).

\subsection{Normalization method}

To normalize protein microarray experiments, we used unlabeled anti-human IgG and IgM antibodies (SigmaAldrich, St. Louis, Mo, USA) in a dilution row from $1 \times 10^{-1}-1 \times 10^{-4}$. Proteins were spotted in duplicate in two identical fields for statistical analysis and to study intramicroarray reproducibility.

\subsection{Western blot}

Proteins were transferred from the polyacrylamide gel onto a PVDF membrane by a semidry procedure. The transfer was carried out for $1 \mathrm{~h}$ at $5 \mathrm{~mA} / \mathrm{cm}^{2}$ in blotting buffer $(20 \mathrm{~mm}$ Tris/HCl, pH 8.0; 150 mm glycine; $20 \% \mathrm{v} / \mathrm{v}$ methanol). The membranes were then blocked with $5 \% \mathrm{w} / \mathrm{v}$ milk powder in TBST (150 mm NaCl; $10 \mathrm{~mm}$ Tris/HCl, pH 7.5; 0.1\% v/v Tween 20) for $1 \mathrm{~h}$ at room temperature. The sera incubation followed overnight at $4^{\circ} \mathrm{C}$ in a dilution of 1:100 in blocking reagent. The membranes were washed five times for $10 \mathrm{~min}$ with TBST. The incubation with the secondary antibody (mouse anti-human IgG; Dianova) followed for $2 \mathrm{~h}$ in a dilution of 1:5000 v/v in blocking reagents at $4^{\circ} \mathrm{C}$. After five wash steps with TBST for $10 \mathrm{~min}$ the incubation with a third antibody (anti-mouse IgG alkaline phosphatase-conjugate; Sigma-Aldrich), diluted 1:5000 v/v in blocking reagent for $1.5 \mathrm{~h}$ at $4^{\circ} \mathrm{C}$ was carried out. Proteins were detected with 5 bromo-4-chloro-3-indolyl phosphate/nitro blue tetrazolium, (NBT-BCIP; Sigma) and the reaction was stopped in distilled water.

\section{Results and discussion}

As phase-variable genes play an important role in pathogenicity of $N$. meningitidis, all such genes identified by the groups of Saunders and Snyder $[12,13]$ from N. meningitidis serogroup B were selected. For these 102 genes, primers were designed starting with a 5' primer to be in frame with the expression vector. Some genes were annotated in the genome with an authentic frameshift in the gene, resulting in the disruption of one single ORF. To solve this problem we 
Table 1. N. meningitidis phase-variable expressed proteins showing an immune response to sera of patients with meningitis. Twenty sera were tested indicated by the number above. In the upper part of the table, additional patient sera information is presented (age: $8 \mathrm{~m}$ indicates 8 months, all other numbers are in years; sex: $\mathrm{f}$, female; $\mathrm{m}$, male; diagnosis: $\mathrm{M}$, meningitis; $\mathrm{S}$, sepsis; MS, meningitis and sepsis; nd, not determined). After statistical calculations and considering controls from healthy persons, the factor presents the increased antibody reaction of a diseased person. For the following proteins (NMB numbers) present on the protein microarrays we could not observe an increased signal ( $\geq 3$ ): 0218, 0270, 0456, 0831, 0884, 0955, 0961, 0983, 1080, 1140, 1200, 1786, 1824, $1846,1900,1913,1929,1969,2032,2093,2145,1255,1261,1265,1275,1377,1379,1467,1489,1507,1543,1760$, and 1783

\begin{tabular}{|c|c|c|c|c|c|c|c|c|c|c|c|c|c|c|c|c|c|c|c|c|c|}
\hline \multirow[t]{2}{*}{ NMB } & \multirow[t]{2}{*}{ Annotation according TIGR } & \multicolumn{20}{|c|}{ Serum number } \\
\hline & & 1 & 2 & 3 & 4 & 5 & 6 & 7 & 8 & 9 & 10 & 11 & 12 & 13 & 14 & 15 & 16 & 17 & 18 & 19 & 20 \\
\hline Infor- & Age of patient & 17 & 11 & 20 & 16 & 33 & 9 & 2 & 6 & 9 & 8 & 14 & 6 & 17 & 5 & 19 & 5 & 19 & 33 & $8 m$ & 15 \\
\hline mation & Sex of patient & $\mathrm{m}$ & $\mathrm{m}$ & $\mathrm{m}$ & $\mathrm{m}$ & $f$ & $\mathrm{~m}$ & $\mathrm{~m}$ & $f$ & $f$ & $f$ & $\mathrm{~m}$ & $\mathrm{~m}$ & f & $\mathrm{f}$ & f & $\mathrm{m}$ & $\mathrm{m}$ & $\mathrm{m}$ & $f$ & $\mathrm{~m}$ \\
\hline to sera & Diagnosis & MS & nd & nd & M & M & M & S & MS & nd & M & $S$ & M & M & M & S & M & nd & M & M & M \\
\hline A1275 & Hypothetical frameshifted protein & & & & & 3 & & & & & & & & & & & & & & & \\
\hline B0831 & $\begin{array}{l}\text { Type I restriction enzyme S protein, } \\
\text { degenerate }\end{array}$ & 3 & & & & & & & & & & & & & & & & 4 & & & \\
\hline B1261 & $\begin{array}{l}\text { Type III restriction-modification } \\
\text { system EcoPI enzyme, authentic } \\
\text { point mutation }\end{array}$ & & & & & & & & & & & & & & & & & 8 & & & \\
\hline 0032 & Hypothetical protein & & & & & & & & & & & & 6 & & 8 & 3 & & & & & \\
\hline 0053 & Conserved hypothetical protein & & & & & 3 & & & & & & & & & 8 & 3 & & 3 & & & \\
\hline 0182 & Outer membrane protein $0 \mathrm{mp} 85$ & 3 & & & & 3 & & & & & & & & & 3 & & & 22 & 4 & & \\
\hline 0300 & Hypothetical protein & & 10 & & & & & & & & & & & & & & & 6 & 3 & & \\
\hline 0312 & $\begin{array}{l}\text { Virulence-associated protein VapA, } \\
\text { authentic frameshift }\end{array}$ & & & & & & & & & & & & & & & & & 3 & & & \\
\hline 0341 & tspA protein & 3 & & & & & 4 & & & & & & & & & & & 6 & & & \\
\hline 0368 & Hypothetical protein & & & & & 4 & & & & & & & & & & & & & & & \\
\hline 0377 & Conserved hypothetical protein & & 12 & & & & & & & & & & & & 8 & & & & 3 & 3 & \\
\hline 0415 & $\begin{array}{l}\text { Conserved hypothetical protein, } \\
\text { authentic frameshift }\end{array}$ & & & & & & & & & & & & & 4 & 3 & 3 & & 3 & & 5 & \\
\hline 0432 & Conserved hypothetical protein & & & & & & & & & & & & & & & & & 6 & & & \\
\hline 0442 & Opacity protein, authentic frameshift & 25 & 3 & 9 & & 19 & 4 & 3 & & 3 & 9 & & 8 & & & & & 25 & 14 & & \\
\hline 0471 & Conserved hypothetical protein & 3 & & & & & & & & & & & & & 22 & & & & & & \\
\hline 0486 & Conserved hypothetical protein & & & & & & & & & & & & 5 & & & & & 3 & & & \\
\hline 0488 & Hypothetical protein & & & & & & & & & & & & & & & & & 8 & 3 & & \\
\hline 0593 & Conserved hypothetical protein & 3 & & & & & & & & & & & 5 & & & & & 20 & 13 & & \\
\hline 0623 & $\begin{array}{l}\text { Spermidine/putrescine ABC trans- } \\
\text { porter, periplasmic spermidine/ } \\
\text { putrescine-binding }\end{array}$ & & & & & & & & & & & & & & & & & 6 & & & \\
\hline 0726 & Type II restriction enzyme Hgal & & & & & & & & & & & & 5 & & 3 & 3 & & 5 & & & \\
\hline 0741 & Conserved hypothetical protein & 3 & & & & & & & & & & & & & & & & 5 & & & \\
\hline 0785 & $\begin{array}{l}\text { Exodeoxyribonuclease V } 135 \mathrm{kDa} \\
\text { polypeptide }\end{array}$ & & & & & & & & & & & & 3 & & & & & 16 & 13 & & \\
\hline 0846 & $\begin{array}{l}\text { LPS biosynthesis protein-related } \\
\text { protein }\end{array}$ & & & & & & & & & & & & & & & 3 & & & & & \\
\hline 0872 & Conserved hypothetical protein & & 5 & & & & & & & & & & & 3 & & & & & & & \\
\hline 0926 & Opacity protein, authentic frameshift & 4 & 4 & & & & & & & & & & & & & & & 5 & & & \\
\hline 0970 & Conserved hypothetical protein & & 6 & & & & & & & & & & & & & & & & & & \\
\hline 1001 & Integrase protein, degenerate & & & & & & & & & & & & & & & & & & 5 & & \\
\hline 1030 & Conserved hypothetical protein & & 4 & & & & & & & & & & & & & & & & 3 & & \\
\hline 1053 & Class 5 outer membrane protein & 4 & & & & & & & & & & & & & & & & & & & \\
\hline 1094 & Hypothetical protein & & & & & & 3 & & & & & & & & & & & & & & \\
\hline 1223 & $\begin{array}{l}\text { Site-specific DNA methylase, } \\
\text { degenerate }\end{array}$ & & 9 & & & & & & & & & & 3 & & 6 & 7 & & & 7 & 3 & 4 \\
\hline 1350 & Hypothetical protein & & & & & 3 & & & & & & & & & & & & & & & \\
\hline 1429 & Outer membrane protein PorA & & & & 8 & & & & & & & & & & & & & & & & \\
\hline 1443 & $\begin{array}{l}\text { DNA polymerase III, subunits gamma } \\
\text { and tau, programmed frameshift }\end{array}$ & & & & 3 & & & & & & & & & 9 & & & & & 3 & & \\
\hline 1540 & Lactoferrin-binding protein $\mathrm{A}$ & & & & & & & & 3 & & & & & & & & & & & & \\
\hline
\end{tabular}


Table 1. Continued

\begin{tabular}{|c|c|c|c|c|c|c|c|c|c|c|c|c|c|c|c|c|c|c|c|c|c|}
\hline \multirow[t]{2}{*}{ NMB } & \multirow[t]{2}{*}{ Annotation according TIGR } & \multicolumn{20}{|c|}{ Serum number } \\
\hline & & 1 & 2 & 3 & 4 & 5 & 6 & 7 & 8 & 9 & 10 & 11 & 12 & 13 & 14 & 15 & 16 & 17 & 18 & 19 & 20 \\
\hline Infor- & Age of patient & 17 & 11 & 20 & 16 & 33 & 9 & 2 & 6 & 9 & 8 & 14 & 6 & 17 & 5 & 19 & 5 & 19 & 33 & $8 m$ & 15 \\
\hline mation & Sex of patient & $\mathrm{m}$ & $\mathrm{m}$ & $\mathrm{m}$ & $\mathrm{m}$ & $f$ & $\mathrm{~m}$ & $\mathrm{~m}$ & $f$ & $f$ & $f$ & $\mathrm{~m}$ & $\mathrm{~m}$ & $f$ & $f$ & $f$ & $\mathrm{~m}$ & $\mathrm{~m}$ & $\mathrm{~m}$ & $f$ & $\mathrm{~m}$ \\
\hline to sera & Diagnosis & MS & nd & nd & M & M & M & S & MS & nd & M & S & $\mathrm{M}$ & M & M & S & M & nd & M & M & M \\
\hline 1636 & Opacity protein, authentic frameshift & & & & 4 & 6 & & & & & 3 & & & & & & & & & & \\
\hline 1734 & Glutaredoxin & & & & & & & & & & & & & & & & & 6 & 3 & & \\
\hline 1741 & $\begin{array}{l}\text { Conserved hypothetical protein, } \\
\text { authentic frameshift }\end{array}$ & & 6 & & & & & & & & & & & & 4 & & & & & & \\
\hline 1836 & $\begin{array}{l}\text { Lipopolysaccharide biosynthesis } \\
\text { protein } \mathrm{WbpC} \text {, putative }\end{array}$ & 3 & & & & 3 & & & & & & & & & & & & & & & \\
\hline 1877 & Prolyl oligopeptidase family protein & & & & & & & & & & & & & & & & 3 & 5 & & & \\
\hline 1893 & $\begin{array}{l}\text { Conserved hypothetical protein, } \\
\text { authentic frameshift }\end{array}$ & & & & & & & & & & & & & & & & & 7 & 5 & & \\
\hline 1931 & Hypothetical protein & & 5 & & & & & & & & & & 3 & & 4 & & & 13 & 12 & & \\
\hline 1985 & Adhesion and penetration protein & & & & & & & & & & & & & & & 3 & & & & & \\
\hline 1988 & $\begin{array}{l}\text { Iron-regulated outer membrane } \\
\text { protein } \operatorname{FrpB}\end{array}$ & & & & & & & & & & & & & & 3 & & & & & & 5 \\
\hline 1994 & Adhesin/invasin, putative & & & & & 8 & & & & & & & & & 7 & & & & & 3 & \\
\hline 1998 & Serine-type peptidase & 3 & & & & & & & & & & & & & & & & & 3 & & \\
\hline 2104 & mafA protein, authentic frameshift & 5 & & & & & & & & & & & & & & & & & & & \\
\hline
\end{tabular}

used two strategies: for genes with an ORF interruption near the 5' end, we designed primers binding 3' of this interruption resulting in one shortened ORF. For genes with an interruption in the middle of the gene, we designed two separate primer pairs flanking this disruption resulting in the generation of two recombinant proteins for one disrupted gene.

Ninety-seven percent of the selected gene constructs could be amplified and used for cloning in an expression vector. The identities of the clones were confirmed by sequencing, and correct clones were used for protein expression. The recombinant $\mathrm{N}$-terminal $\mathrm{His}_{6}$-tag fusion proteins were purified and the purification was monitored by Bradford assay and SDS-PAGE (Fig. 1).

Out of the initial 102 phase-variable genes, we were able to express and purify 91 recombinant RGS-His ${ }_{6}$ fusion-protein constructs, corresponding to 67 annotated genes, which correlates to an overall success rate of $66 \%$. The concentration of the purified proteins averaged around $200 \mu \mathrm{g} / \mathrm{mL}$ with a size ranging from $7 \mathrm{kDa}$ (NMB2145) to $160 \mathrm{kDa}$ (NMB1985). Eleven constructs, mostly transporter proteins, did not express any protein. With one of them, NMB0098, we experienced a bacteriostatic effect in E. coli following induction of protein expression using IPTG (data not shown).

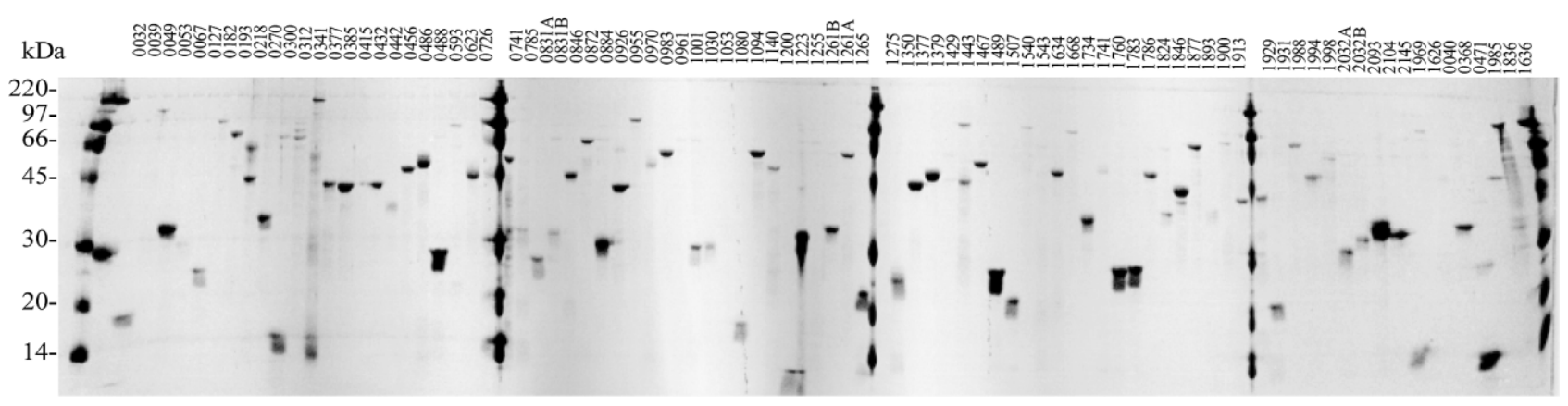

Figure 1. SDS-PAGE of $N$. meningitidis proteins (Coomassie stained), after purification using a QIAGEN BioRobot 8000 in a $96-$-well format. Up to $600 \mu \mathrm{g}$ protein (eluted in $350 \mu \mathrm{L}$ buffer) were obtained from $2 \mathrm{~mL}$ culture medium. Approximate sizes of the protein markers are shown on the left in $\mathrm{kDa}$. 


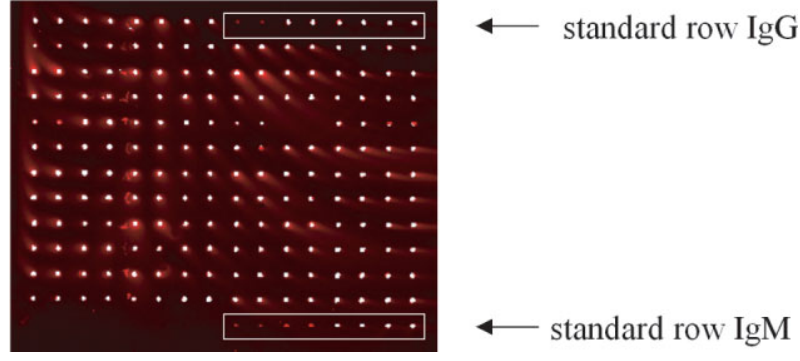

Figure 2. Protein microarray with 91 different recombinant bacterial $\mathrm{RGS}^{-\mathrm{His}_{6}}$ fusion-proteins spotted in duplicate on FAST slides in a $4 \times 4$ pattern (the protein NMB0057 was spotted twice in duplicate). The recombinant $\mathrm{RGS}^{-\mathrm{His}_{6}}$ fusion-protein constructs correspond to 67 annotated genes. The microarray was screened with anti-RGS-His antibodies, followed by the detection with a Cy5 labeled secondary antibody. Both red and white signals indicate antibody binding, where white indicates strong and red intermediate signals. Anti-lgG and $-\lg M$ antibodies were spotted in dilution rows up to $10^{-4}$ as standards (boxes).

For the generation of protein microarrays NC-coated slides were used, since the 3-D structure of the coating provides a much greater binding capacity than 2 -D surfaces [34, 35]. Spotting and immobilization were checked by incubation with anti-RGS-His ${ }_{6}$ antibodies, which were visualized with Cy5-labeled secondary antibodies (Fig. 2).

For serum screening, the microarrays were incubated with sera from patients having meningitis as well as healthy control patients. We studied 20 patients, both female and male, aged from 8 months to 33 years as well as 12 control patients. Normalization was performed with a set of antihuman IgG and IgM antibody standards in accordance with the study of Robinson et al. [32]. The results were subjected to the 1-Sample Gaussian test and all proteins with a value $\geq 3$ were accounted as targets of the immune response and listed in Table 1. Some sera did not show any immune responses, in twelve sera $\leq 5$ proteins could be detected, in four sera 6-10 proteins were positive, three sera yielded 1015 proteins, and one serum 22 different phase-variable expressed proteins. Such a variability of the immune response has been observed previously and is independent of the particular person from whom the serum was obtained $[36,37]$. The reason for this is the varying susceptibility of a particular strain to human antibody and complement.

Only the protein OpaV (NMB0442) was detected with high reproducibility in 11 out of 20 sera (Fig. 3). This protein OpaV shows similarities to Opa proteins. We could confirm the results obtained by the microarray analysis by Western blot. In Western blots the protein OpaV was detected only by patient sera and not with the control sera (Fig. 4). Additional protein bands that were visible in the gel represent degradation products of these proteins as proven by MS analysis (data not shown).

The exact function of OpaV is still unknown. The TIGR annotation (http://www.tigr.org), for this gene predicted no protein, as it has an authentic frameshift. From the gene homology it belongs to the group of Opa proteins. Opa proteins are integral outer membrane proteins that are synthesized as precursors containing signal sequences for inner membrane transport. Parts of the leader peptide of Opa proteins are encoded by repetitive coding repeats of CTTCT pentameric units. The number of repeat units found in genes and mRNA is subject to frequent and precise changes. Such changes affect the expression of individual Opa genes at the translational level [38]. A serum Opa protein is present in Streptococcus pyogenes that is surface bound and contains both variable and conserved domains. It was shown that this protein is a virulence factor and leads to infection in the pharynx [39]. This indicates a correlation to the function of the protein OpaV. As shown for N. gonorrhoeae [40, 41], Opa proteins play an important role in the penetration of Neisseria into host cells as studied in cell culture experiments [40, 41]. N. meningitidis harbors four Opa proteins: OpaV (NMB0442), NMB0926, NMB1636, and NMB1465. For NMB1465 we could not generate a recombinant protein successfully. The other three proteins were analyzed using protein microarrays and Western blots and have the following degree of similarity compared to OpaV: NMB0926 (94\%), NMB1636 (78\%). In Western blot analysis probed using patient and control sera strong signals could be seen only for OpaV and NMB0926 indicating expression during meningitis (Fig. 5 and Table 1).
A)

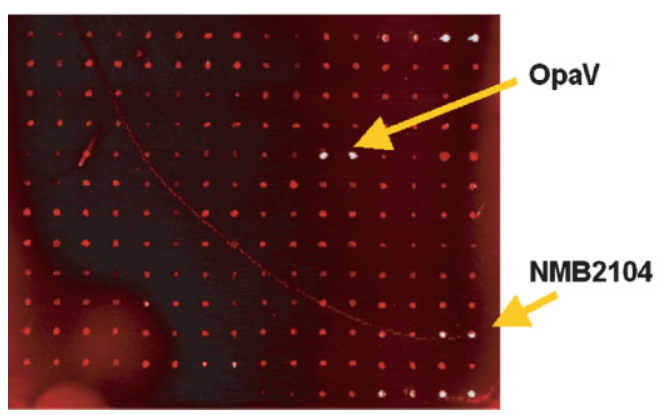

B)

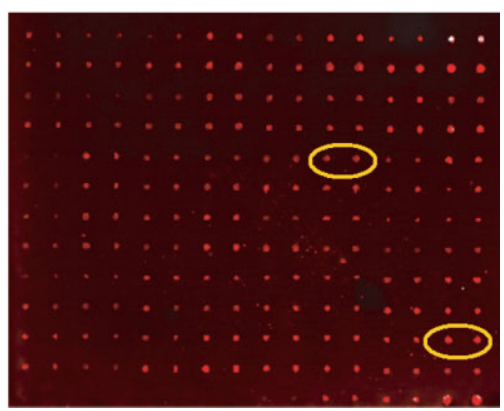

Figure 3. Exemplary result of a protein microarray screened with $(A)$ serum of a patient and (B) serum of a control person. Bound serum antibodies to spotted proteins were detected with Cy5 labeled secondary antibodies. White signals indicate a strong antibody reaction to the proteins OpaV (NMB0442; arrows) and NMB2104 (circles) that were only visible in the patient serum. 
A)

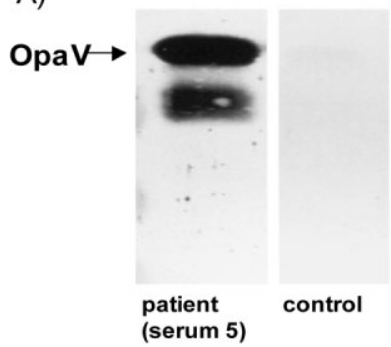

B)

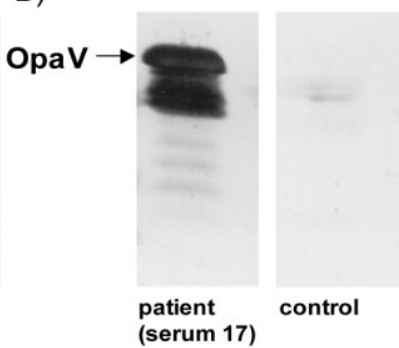

Figure 4. Western blot experiment screened with (A) serum number 5 and control and (B) serum number 17 and control. Proteins were detected using alkaline phosphatase. The additional protein bands are degradation products, as checked by MS analysis.

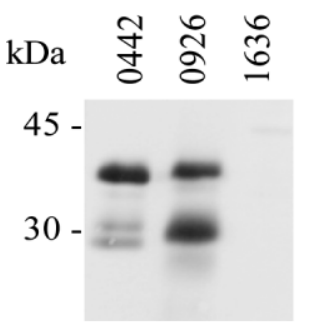

serum 1

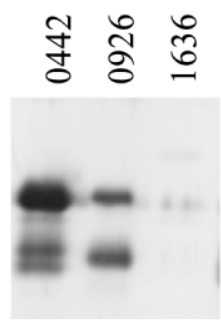

serum 17

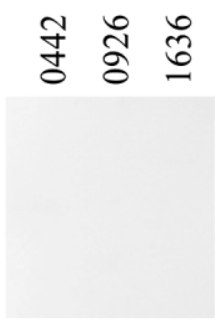

control

Figure 5. Western blot analysis of the Opa proteins of $N$. meningitidis screened with two patient sera and a control serum. Proteins were detected using alkaline phosphatase. The additional protein bands are degradation products, as verified by MS analysis.

\section{Concluding remarks}

In the present study, we have investigated phase-variable genes of N. meningitidis. Ninety-one recombinant RGS-His 6 fusion-protein constructs, corresponding to 67 annotated genes, were expressed and tested with patient sera and compared to controls. Forty-seven proteins could be identified by fluorescent signals, indicating seroreactivity. The protein OpaV could be identified by 11 out of 20 sera, demonstrating its immunogenicity. This indicates that this phase-variable gene, predicted with an authentic frameshift, is expressed during meningococcal infection.

Investigation of new potential diagnostic markers is of outstanding interest as there is presently an upsurge of meningococcal infection worldwide, particularly due to serogroup B, for which still no effective vaccine is available.

Pathogen protein microarrays will become an important tool to explore new diagnostic markers as well as for the monitoring of immune responses to newly developed vaccines [42-45].

We are thankful for the critical reading of the manuscript by Jörn F. Glökler. We are grateful to Dr. Marlies Höck (DRK Kliniken, Berlin, Germany) for providing control sera. D.J.C.

acknowledges the support of the Health Education Authority, Dublin 2, Ireland and the BMBF (BioFuture, Förderkennzeichen 0311870). This project was supported by the European Union Grant \# QLRT-CT-1999-00359.

\section{References}

[1] Tikhomirov, E., Santamaria, M., Esteves, K., World Health Stat. Q. 1997, 50, 170-177.

[2] Jennings, M. P., Virji, M., Evans, D., Foster, V. et al., Mol. Microbiol. 1998, 29, 975-984.

[3] Hammerschmidt, S., Muller, A., Sillmann, H., Muhlenhoff, M. et al., Mol. Microbiol. 1996, 20, 1211-1220.

[4] Sarkari, J., Pandit, N., Moxon, E. R., Achtman, M., Mol. Microbiol. 1994, 13, 207-217.

[5] van der Ende, A., Hopman, C. T., Zaat, S., Essink, B. B. et al., J. Bacteriol. 1995, 177, 2475-2480.

[6] Lewis, L. A., Gipson, M., Hartman, K., Ownbey, T. et al., Mol. Microbiol. 1999, 32, 977-989.

[7] Jennings, M. P., Srikhanta, Y. N., Moxon, E. R., Kramer, M. et al., Microbiology 1999, 145, 3013-3021.

[8] Virji, M., Makepeace, K., Ferguson, D. J., Achtman, M., Moxon, E. R., Mol. Microbiol. 1993, 10, 499-510.

[9] Virji, M., Makepeace, K., Peak, I. R., Ferguson, D. J. et al., Mol. Microbiol. 1995, 18, 741-754.

[10] Jennings, M. P., Hood, D. W., Peak, I. R., Virji, M., Moxon, E. R., Mol. Microbiol. 1995, 18, 729-740.

[11] Tettelin, H., Saunders, N. J., Heidelberg, J., Jeffries, A. C. et al., Science 2000, 287, 1809-1815.

[12] Saunders, N. J., Jeffries, A. C., Peden, J. F., Hood, D. W. et al., Mol. Microbiol. 2000, 37, 207-215.

[13] Snyder, L. A., Butcher, S. A., Saunders, N. J., Microbiology 2001, 147, 2321-2332.

[14] Martin, P., van de Ven, T., Mouchel, N., Jeffries, A. C. et al., Mol. Microbiol. 2003, 50, 245-257.

[15] Moxon, E. R., Rainey, P. B., Nowak, M. A., Lenski, R. E., Curr. Biol. 1994, 4, 24-33.

[16] Kristiansen, B. E., Ask, E., Jenkins, A., Fermer, C. et al., Lancet 1991, 337, 1568-1569.

[17] Kotilainen, P., Jalava, J., Meurman, O., Lehtonen, O. P. et al., J. Clin. Microbiol. 1998, 36, 2205-2209.

[18] Templin, M. F., Stoll, D., Schrenk, M., Traub, P. C. et al., Trends Biotechnol. 2002, 20, 160-166.

[19] Templin, M. F., Stoll, D., Schwenk, J. M., Potz, O. et al., Proteomics 2003, 3, 2155-2166.

[20] Glökler, J., Angenendt, P., J. Chromatogr. B. Analyt. Technol. Biomed. Life Sci. 2003, 797, 229-240.

[21] Bussow, K., Cahill, D., Nietfeld, W., Bancroft, D. et al., Nucleic Acids Res. 1998, 26, 5007-5008.

[22] Zhu, H., Klemic, J. F., Chang, S., Bertone, P. et al., Nat. Genet. 2000, 26, 283-289.

[23] Michaud, G. A., Salcius, M., Zhou, F., Bangham, R. et al., Nat. Biotechnol. 2003, 21, 1509-1512.

[24] Angenendt, P., Wilde, J., Kijanka, G., Baars, S. et al., Anal. Chem. 2004, 76, 2916-2921.

[25] Rowe, C. A., Scruggs, S. B., Feldstein, M. J., Golden, J. P., Ligler, F. S., Anal. Chem. 1999, 71, 433-439. 
[26] Haab, B. B., Dunham, M. J., Brown, P. O., Genome Biol. 2001, 2, RESEARCH0004.

[27] Bacarese-Hamilton, T., Bistoni, F., Crisanti, A., Biotechniques 2002, Suppl., 24-29.

[28] Hiller, R., Laffer, S., Harwanegg, C., Huber, M. et al., FASEB J. 2002, 16, 414-416.

[29] Lueking, A., Possling, A., Huber, O., Beveridge, A. et al., Mol. cell Proteomics 2003, 2, 1342-1349 (Epub 2003 Sep 29).

[30] MacBeath, G., Schreiber, S. L., Science 2000, 289, 17601763.

[31] Angenendt, P., Lehrach, H., Kreutzberger, J., Glökler, J., Proteomics 2005 5, 420-425.

[32] Robinson, W. H., DiGennaro, C., Hueber, W., Haab, B. B. et al., Nat. Med. 2002, 8, 295-301.

[33] Bradford, M. M., Anal. Biochem. 1976, 72, 248-254.

[34] Angenendt, P., Glökler, J., Murphy, D., Lehrach, H., Cahill, D. J., Anal. Biochem. 2002, 309, 253-260.

[35] Angenendt, P., Glökler, J., Sobek, J., Lehrach, H., Cahill, D. J., J. Chromatogr. A. 2003, 1009, 97-104.
[36] Tramont, E. C., Sadoff, J. C., Wilson, C., J. Immunol. 1977, 118, 1843-1851.

[37] Mahler, E., Hoebeke, J., Levin, M. J., Clin. Exp. Immunol. 2004, 136, 527-534.

[38] Muralidharan, K., Stern, A., Meyer, T. F., Antonie Van Leeuwenhoek 1987, 53, 435-440.

[39] Courtney, H. S., Hasty, D. L., Dale, J. B., Infect. Immun. 2003, 71, 5097-5103.

[40] van Putten, J. P., Robertson, B. D., Mol. Microbiol. 1995, 16, 847-853.

[41] Freissler, E., Meyer auf der Heyde, A., David, G., Meyer, T. F., Dehio, C., Cell Microbiol. 2000, 2, 69-82.

[42] Pandey, A., Mann, M., Nature 2000, 405, 837-846.

[43] Sun, Y. H., Bakshi, S., Chalmers, R., Tang, C. M., Nat. Med. 2000, 6, 1269-1273.

[44] Wren, B. W., Nat. Rev. Genet. 2000, 1, 30-39.

[45] Pizza, M., Scarlato, V., Masignani, V., Giuliani, M. M. et al., Science 2000, 287, 1816-1820. 